\title{
OPERASI MORFOLOGI UNTUK MENDETEKSI KEBERADAAN BENDA TAJAM PADA CITRA X-RAY DI BANDARA
}

\section{Oleh: \\ NURUL ZAINAL FANANI *)}

\begin{tabular}{|l|} 
ABSTRAK \\
Pemeriksaan barang bawaan penumpang adalah hal yang mutlak dilakukan sebelum seseorang memasuki \\
kabin pesawat untuk mengantisipasi masuknya benda berbahaya kedalam pesawat. Penentuan adanya \\
benda berbahaya dalam tas bawaan penumpang dilakukan oleh petugas security dengan mengamati \\
monitor pada mesin $x$-ray bandara. Faktor kelelahan petugas sangat mempengaruhi tingkat akurasi pada \\
proses pemeriksaan tersebut. \\
Sehingga pada penelitian ini dibuat perangkat lunak yang dapat diaplikasikan pada mesin $x$-ray guna \\
membantu petugas security dalam menentukan adanya benda tajam yang diindikasikan sebagai barang \\
berbahaya. Proses deteksi benda tajam diawali dengan segmentasi menggunakan Color base, proses \\
filtering menggunakan Morfologi serta penentuan tajam atau tidaknya objek menggunakan Round Value.
\end{tabular}

Kata kunci: $\mathrm{x}$-ray bandara, segmentasi berbasis warna, operasi morfologi

\section{PENDAHULUAN}

Keamanan dan keselamatan penumpang merupakan salah satu hal yang sangat penting dalam dunia penerbangan komersial. Barangbarang yang dianggap berbahaya (Prohibited Item) seperti pisau, gunting, korek api, senjata api dilarang dibawa masuk oleh penumpang kedalam kabin pesawat (Peraturan Direktur Jendral Perhubungan Udara, 2010). Untuk mengantisipasi agar barang-barang berbahaya tersebut tidak masuk kedalam kabin pesawat, dilakukan proses pemindaian barang bawaan penumpang menggunakan mesin X-Ray atau Body Inspection Machine (Peraturan Direktur Jendral Perhubungan Udara, 2010) di setiap bandara. Dari mesin tersebut akan dapat diketahui apakah penumpang membawa barang berbahaya atau tidak. Pemeriksaan barang bawaan penumpang menggunakan mesin $X$-Ray masih dilakukan secara manual oleh petugas keamanan di tempat pemeriksaan keamanan (Security Check Point/SCP). Pada jam sibuk, petugas dituntut untuk mengambil keputusan dengan cepat apakah didalam tas penumpang terdapat barang berbahaya atau tidak. Terkadang petugas melakukan kesalahan dalam pemeriksaan akibat kelelahan fisik. Untuk memperkecil kelalaian oleh petugas, diperlukan sebuah perangkat lunak yang mampu mendeteksi barang berbahaya dari citra pada mesin $X$-ray di bandara.
Penelitian mengenai pemeriksaaan barang terlarang (prohibited items) menggunakan mesin $X$-Ray telah banyak dilakukan. Hardmeier (Hardmeier D, 2005) menggunakan X-Ray Object recognition Test (X-Ray ORT) untuk mengukur kemampuan visual pemeriksaan image hasil screening X-Ray. Hardmeier mempelajari kemampuan X-Ray ORT memvisualisasikan prohibited items jika berada dalam beberapa kondisi yaitu berada dalam tas kompleks, superposisi atau tumpang tindih dan berada dalam sudut pandang yang berbeda. Pada penelitian Schwaninger (Schwaninger A, 2007) menggunakan pendekatan statistik untuk mengatasi kesulitan estimasi citra pada pemeriksaan X-Ray menggunakan image measurement. Kedua penelitian tersebut hanya mempelajari apakah citra hasil screening X-Ray yang terdapat prohibited items masih dapat dikenali oleh petugas keamanan meskipun prohibited items tersebut berada dalam tas kompleks, superposisi atau tumpang tindih dan berada dalam sudut pandang yang berbeda (viewpoint). Pada kedua penelitian tersebut, penentuan adanya barang terlarang (prohibited items) dalam tas bawaan penumpang tetap dilakukan oleh petugas. Penelitian tersebut belum mempelajari aspek kelelahan fisik yang dapat mengakibatkan terlewatnya tas penumpang yang 
berisi barang terlarang (prohibited items) terbawa kedalam kabin pesawat.

Oleh karena itu penelitian ini mempelajari bagaimana mengidentifikasi adanya barang terlarang (prohibited items) pada citra $X$ Ray hasil screening mesin X-Ray bandara, kemudian memberitahu petugas keamanan tentang keberadaan prohibited items tersebut sehingga diharapkan dapat membantu memperkecil kelalaian petugas keamanan bandara akibat kelelahan fisik.

Penelitian ini mengidentifikasi salah satu prohibited items yaitu benda tajam pada citra $X$ -
Ray hasil screening mesin X-Ray bandara. Sebelum proses identifikasi, dilakukan proses segmentasi untuk mendapatkan benda tajam pada citra menggunakan metode color-based segmentation dan morphological processing. Morphological processing dilakukan dengan tujuan untuk mengurangi noise dan memperhalus citra (Khaparde A, 2010) sehingga memudahkan pada proses selanjutnya. Pada proses identifikasi dilakukan perhitungan round value untuk mengetahui objek adalah benda tajam atau bukan.

\section{Desain Sistem Deteksi Benda Tajam pada Citra X-Ray Bandara}

Secara umum, desain sistem benda tajam pada citra x-ray bandara menggunakan color based segmentation dan morphological filtering seperti pada gambar 3.1.

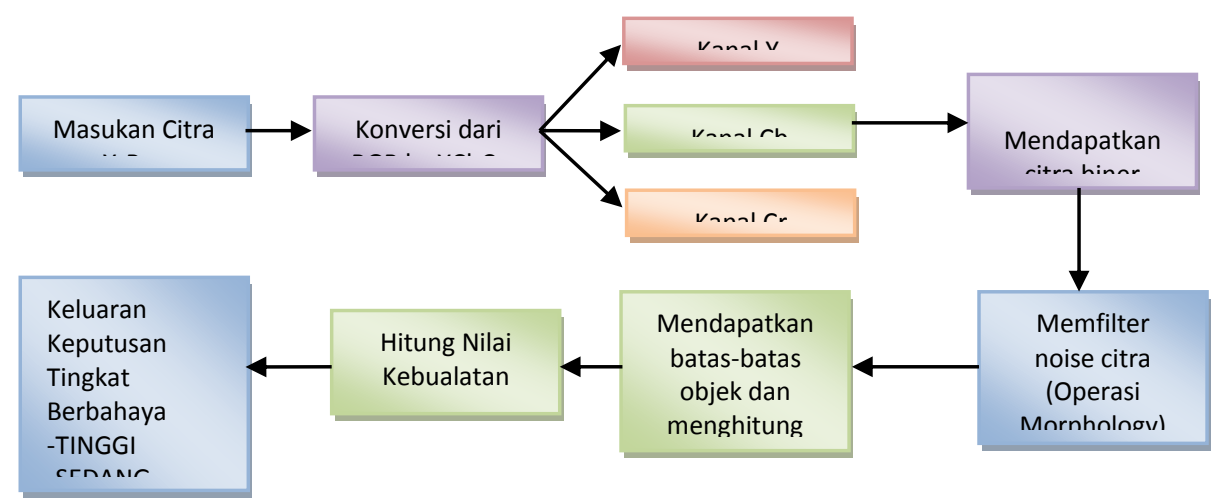

\section{Gambar 3.1 Diagram Blok Sistem}

Seperti terlihat pada gambar 3.1, proses deteksi benda tajam dimulai dengan mengolah citra dari hasil pemindaian mesin X-Ray bandara. Citra kemudian dikonversi dari citra $R G B$ ke citra $\mathrm{YCbCr}$. Proses berikutnya adalah proses segmentasi citra serta menghilangkan noise menggunakan morphological filtering. Setelah dilakukan proses filtering, dari citra tersebut dicari batasnya menggunakan metode deteksi bidang batas (boundary detection) untuk masing-masing objek serta dilabeli untuk setiap objek yang ditemukan. Masing-masing objek dihitung tingkat kebulatannya, apabila obyek memiliki tingkat kebulatan/kebundaran yang kecil dapat diasumsikan bahwa objek tersebut adalah benda tajam. Untuk lebih detail dari tahapan proses diatas akan dijelaskan pada subbab tersendiri.

Untuk mengimplementasikan rancangan sistem pada blok diagram diatas maka dibuat diagram alur simulasi perangkat lunak seperti ditunjukkan pada gambar 3.2.
Proses deteksi benda tajam sebagai barang berbahaya (prohibited item) dimulai dengan memproses citra dari hasil pemindaian mesin $X$-Ray bandara. Benda logam pada citra $X$ Ray cenderung berwarna biru, sehingga untuk dapat mensegmentasi objek benda tajam dengan objek yang lain dilakukan dengan mengubah format citra yang masih berformat $R G B$ kedalam format $\mathrm{YCbCr}$.

Proses selanjutnya adalah proses Thresholding yaitu proses yang bertujuan untuk memisahkan objek benda tajam dengan latar belakangnya (background) menggunakan nilai threshold $=130$. Nilai 130 diperoleh dari hasil pengujian. Citra yang telah diubah dalam format $Y C b C r$, diambil nilai $C b$ dari tiap piksel untuk dibandingkan dengan nilai threshold tersebut. Jika nilai $\mathrm{Cb}$ dari suatu piksel lebih dari nilai threshold = 130 maka nilai piksel akan diubah menjadi 1 . Dan sebaliknya, jika nilai $C b$ dari suatu piksel 
kurang dari nilai threshold $=130$ maka nilai piksel diubah menjadi 0 .

Dari proses thresholding diperoleh citra biner (binary image) dan fitur dari obyek, akan tetapi masih terdapat noise pada citra. Untuk mengurangi noise tersebut, dilakukan proses filtering menggunakan operasi morphology. Setelah proses filtering, maka dicari batas-batas (boundary) untuk menentukan objek yang dicari pada citra biner. Setelah objek ditemukan, kemudian dihitung tingkat kebulatan/kebundaran

(round value) untuk masing-masing objek menggunakan shape factor. Apabila nilai round value (RV) kurang dari 0,44 maka obyek dianggap sebagai benda logam tajam atau barang dengan tingkat bahaya yang tinggi, apabila nilai RV antara 0,44-0,7 maka benda logam diidentifikasi sebagai barang yang tidak tajam, apabila nilai RV 0,7-1 maka benda logam diidentifikasi sebagai barang yang tidak berbahaya. Untuk nilai RV akan dicari nilai yang tepat untuk masing-masing objek yang berbeda.

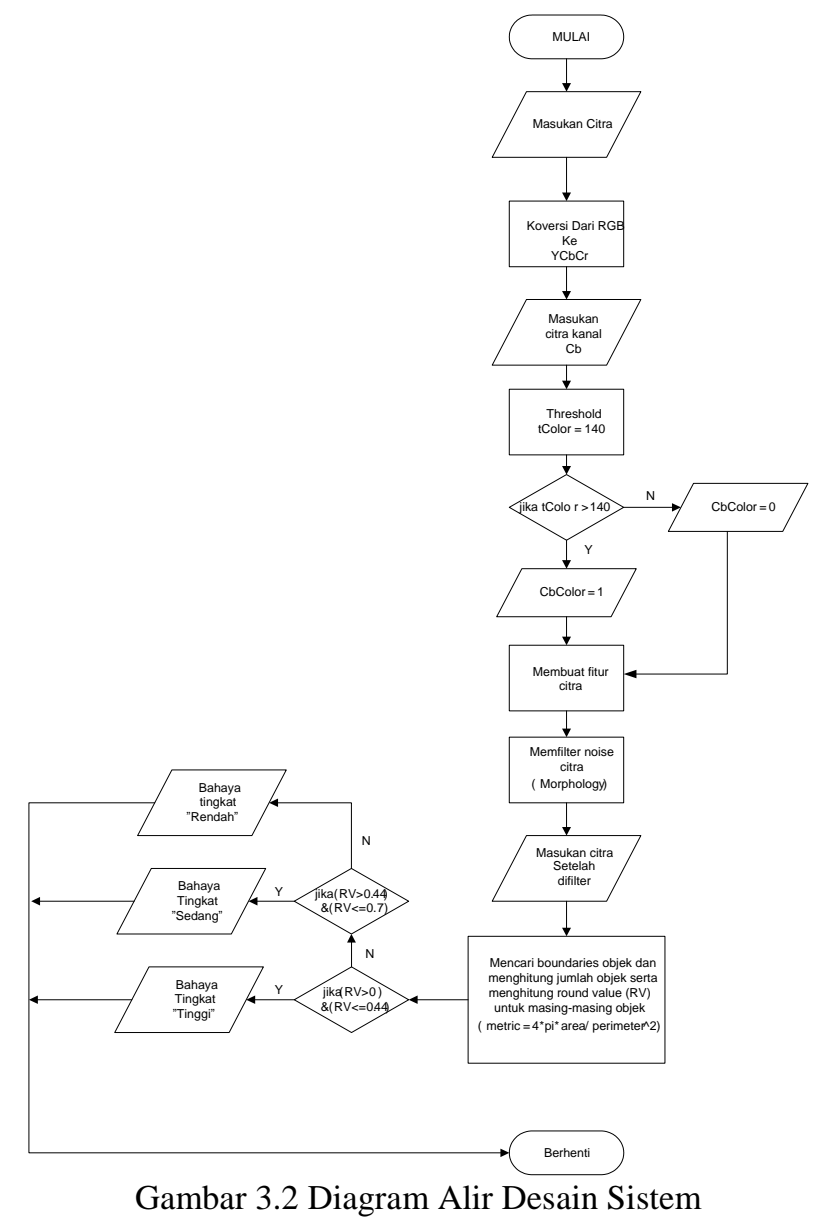

Dari proses thresholding diperoleh citra biner (binary image) dan fitur dari obyek, akan tetapi masih terdapat noise pada citra. Untuk mengurangi noise tersebut, dilakukan proses filtering menggunakan operasi morphology. Setelah proses filtering, maka dicari batas-batas (boundary) untuk menentukan objek yang dicari pada citra biner. Setelah objek ditemukan, kemudian dihitung tingkat kebulatan/kebundaran (round value) untuk masing-masing objek menggunakan shape factor. Apabila nilai round value (RV) kurang dari 0,44 maka obyek dianggap sebagai benda logam tajam atau barang dengan tingkat bahaya yang tinggi, apabila nilai RV antara 0,44-0,7 maka benda logam diidentifikasi sebagai barang yang tidak tajam, apabila nilai RV 0,7-1 maka benda logam diidentifikasi sebagai barang yang tidak berbahaya. Untuk nilai RV akan dicari nilai yang tepat untuk masing-masing objek yang berbeda.

\subsection{Citra Masukan Dari Hasil Mesin X-ray Bandara}

Gambar yang ditampilkan pada display monitor mesin X-Ray bandara mempunyai beberapa warna berdasarkan atom material yang dideteksi yaitu warna orange menunjukkan material organic, warna hijau menunjukkan material unorganik serta warna biru menunjukkan barang/bahan dari logam. 
Pada penelitian ini, benda tajam sebagai obyek yang dideteksi merupakan barang yang terbuat dari logam. Selain bertujuan untuk membedakan obyek yang terbuat dari logam, penelitian ini juga membedakan apakah obyek tersebut merupakan benda tumpul atau benda tajam.
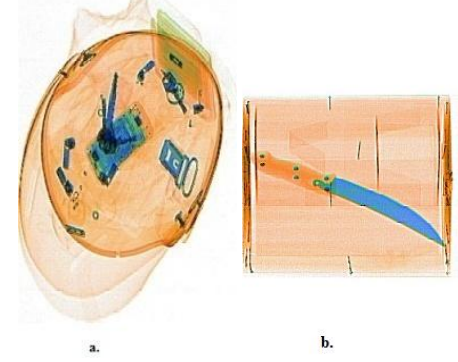

Gambar 3.3 a. Citra X-ray tanpa pisau b. citra X-ray pisau

Gambar 3.3 menunjukkan citra dari mesin X-Ray bandara. Dimana gambar 3.3a merupakan citra dengan obyek tanpa terdapat benda tajam, sedangkan gambar 3.3b merupakan citra dari obyek benda tajam yaitu pisau yang terbuat dari logam.

\section{HASIL DAN PEMBAHASAN}

\subsection{Konversi Citra Dari Format RGB ke YCbCr}

Konversi citra ini dilakukan untuk merubah format citra dari hasil mesin $\mathrm{X}$-ray bandara yang berformar RGB ke YCbCr. Dari gambar 4.1a terlihat citra yang masih berformat RGB. Sedang gambar 4.1b merupakan citra hasil konversi ke format $\mathrm{YCbCr}$.

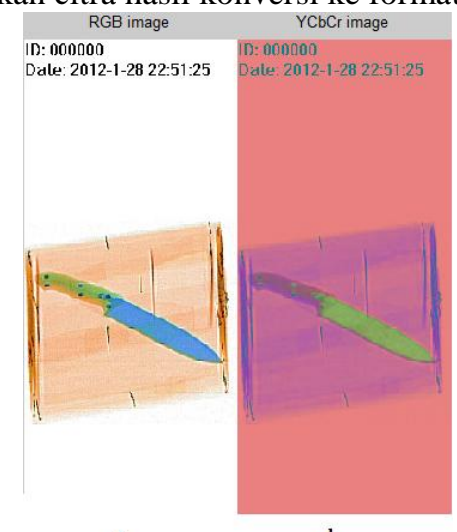

Gambar 4.1 a.Citra Format RGB. B. Citra Format YCbCr

Dari gambar 4.1 (b) terlihat objek pisau yang awalnya pada format RGB berwarna biru, terlihat berwarna hijau pada format $\mathrm{YCbCr}$.

\subsection{Membagi Citra Ke Masing-masing Kanal}

Citra yang telah dirubah keformat $\mathrm{YCbCr}$ kemudian dibagi kedalam masing-masing kanal warna yaitu kanal Y, kanal Cb, dan kanal Cr. Gambar 4.2 memperlihatkan pembagian citra yang berformat $\mathrm{YCbCr}$ kedalam masing-masing kanal. lebih lanjut.

Karena logam dari citra mesin x-ray cenderung berwarna biru maka kanal $\mathrm{Cb}$ yang akan diproses 


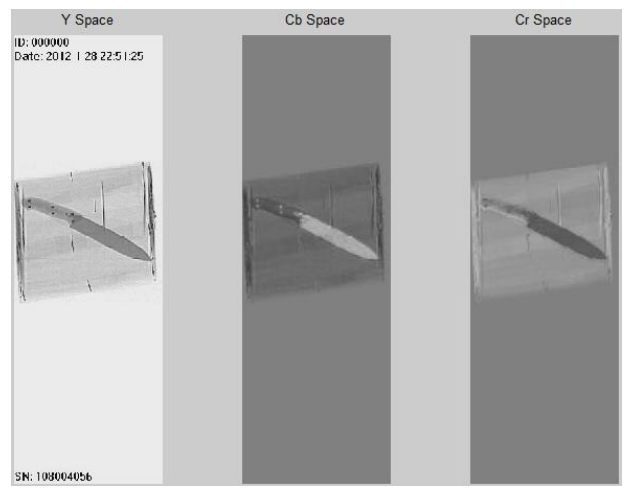

Dari proses pembagian citra segmentation, dimana piksel yang mempunyai berdasarkan kanal $\mathrm{Y}$, kanal $\mathrm{Cb}$, dan kanal nilai lebih dari nilai threshold yaitu 132 maka nilai $\mathrm{Cr}$,terlihat objek pisau sangat menonjol pada citra warna $\mathrm{Cb}$ akan diberi nilai 0 , sebaliknya apabila di kanal Cb. Citra pisau pada kanal Y dan kanal $\mathrm{Cr} \quad$ nilai piksel yang

relative sama. Sehingga untuk proses berikutnya pengolahan citra dari kanal tersebut kurang sesuai.

\subsection{Segmentasi Citra}

Citra yang berasal dari kanal $\mathrm{Cb}$ kemudian disegmentasi menggunakan threshold

dimiliki kurang dari nilai threshold maka nilai warna $\mathrm{Cb}$ diberi nilai 1. Gambar 4.3 menunjukkan hasil segmentasi menggunakan proses thresholding

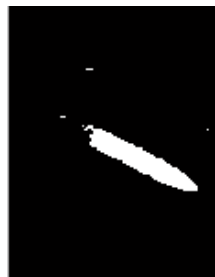

Gambar 4.3 Hasil segmentasi menggunakan proses thresholding.

Dari gambar 4.3 terlihat bahwa citra dari kanal $\mathrm{Cb}$ yang telah melalui proses segmentasi berdasarkan nilai thresholdnya sudah mulai tampak objek pisaunya. Namun apabila diamati masih terdapat noise pada citra tersebut. Hal ini terjadi karena objek dari bahan logam selain pisau masih terdeteksi, sehingga perlu proses perbaikan citra dengan teknik filtering.

\subsection{Memfilter Citra Menggunakan Operasi Morfologi \\ Dari citra yang telah tersegmentasi, proses berikutnya adalah memfilter citra menggunakan operasi morfologi. Untuk}

menghilangkan noise berupa objek-objek kecil yang dihasilkan dari objek bukan pisau seperti resleting, kunci digunakan teknik menghilangkan piksel yang mempunya ukuran kurang dari 30 piksel. Namun pada percobaan berikutnya nilai 30 ini akan dirubah-rubah sampai diperoleh nilai yang paling tepat dimana noise dapat dihilangkan dan objek pisau itu sendiri masih dapat teridentifikasi. Proses berikutnya adalah memperhalus objek menggunakan teknik closing. Dari berbagai proses tersebut akan diperoleh citra dengan objek yang lebih baik. Gambar 4.4 menunjukkan proses sebelum dan sesudah filterisasi. 



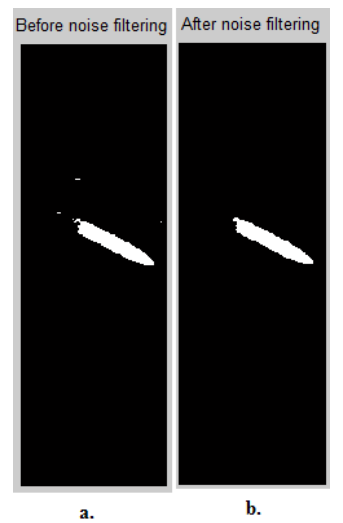

Gambar 4.4 a. Sebelum difilter. b. Setelah difilter.

Citra yang telah mengalami proses filtering terlihat lebih smooth dan noise yang dihasilkan oleh benda-benda logam kecil selain pisau telah telah hilang.

\subsection{Pencarian Batas-batas Objek dan objek yang ditemukan akan diberi warna yang Penghitungan Tingkat Kebulatan Objek. \\ Setelah proses filterisasi menggunakan berbeda untuk masing-masing objek. Kemudian dilanjutkan dengan menghitung tingkat kebulatan operasi morfologi, proses berikutnya adalah mencari batas-batas untuk masing-masing objek. Dari proses ini akan diperoleh jumlah objek yang terdapat pada citra tersebut. Dari masing-masing dari masing-masing objek yang ditemukan, serta member kesimpulan apakah objek yang ditemukan tersebut merupakan barang berbahaya dengan tingkat bahaya yang tinggi, sedang atau rendah.}

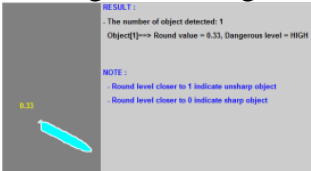

Gambar 4.5 Hasil identifikasi objek pisau.

Gambar 4.5 menunjukkan, terdeteksinya sebuah objek dengan nilai kebulatan 0,33 , sehingga dapat disimpulkan bahwa objek tersebut diindikasikan sebuah pisau dengan tingkat bahaya yang tinggi. Nantinya tidak menutup kemungkinan terdapat lebih dari satu objek yang terdeteksi. Dan untuk masing-masing objek yang terdeteksi dapat dilihat tingkat kebulatan serta tingkat bahayanya.

\subsection{Perubahan Piksel Minimal Pada Proses Filtering}

Percobaan ini dilakukan untuk paling efektif untuk menghilangkan noise objek yang tidak diperlukan, namun informasi objek pisaunya sendiri tidak hilang. Gambar 4.6 menunjukkan contoh citra dengan noise yang cukup besar. Gambar 4.7 menunjukkan citra pisau dengan posisi miring. Saat posisi miring citra dengan objek pisau setelah melalui proses segmentasi mempunyai nilai piksel cenderung lebih kecil, sehingga perlu dicari nilai piksel minimal untuk menghilangkan noise pada proses filtering, namun objek pisau itu sendiri juga tidak hilang. mengetahui berapa nilai piksel minimal yang

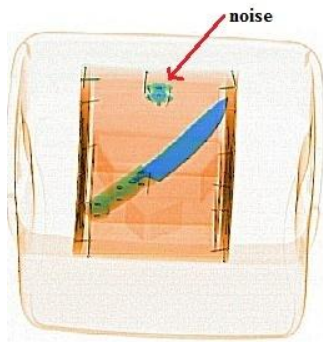

Gambar 4.6 Contoh citra dengan noise cukup besar 


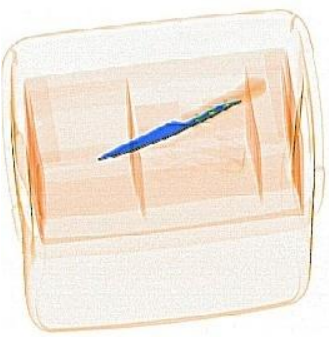

Gambar 4.7 Contoh citra pisau dengan posisi miring.

Tabel 4.1 menunjukkan perubahan nilai piksel minimal pada proses filtering dimana dicari nilai piksel minimal namun tidak menghilangkan informasi dari objek pada proses filtering.

Tabel 4.1 Perubahan nilai piksel minimal pada proses filtering.

\begin{tabular}{|c|c|c|c|}
\hline No. & Objek & $\begin{array}{c}\text { Nilai } \\
\text { piksel } \\
\text { minimal }\end{array}$ & $\begin{array}{c}\text { Jumlah Objek } \\
\text { teridentifikasi }\end{array}$ \\
\hline 1 & 1 & 30 & 2 \\
\hline 2 & 1 & 50 & 2 \\
\hline 3 & 1 & 70 & 2 \\
\hline 4 & 1 & 90 & 2 \\
\hline 5 & 1 & 110 & 1 \\
\hline 6 & 1 & 130 & 1 \\
\hline 7 & 2 & 30 & 2 \\
\hline 8 & 2 & 50 & 1 \\
\hline 9 & 2 & 70 & 1 \\
\hline 10 & 2 & 90 & 1 \\
\hline 11 & 2 & 110 & 1 \\
\hline 12 & 2 & 130 & 1 \\
\hline
\end{tabular}

Dari tabel 4.1 dapat dilihat bahwa perubahan nilai piksel minimal pada proses filtering sangat mempengaruhi jumlah objek yang terdeteksi dimana semakin besar nilai pikselnya maka objek yang terdeteksi akan berkurang. Nilai

\subsection{Tingkat Akurasi Pada Setiap Perubahan Objek}

Percobaan kali ini bertujuan untuk mengetahui seberapa akurat perangkat lunak dapat mengidentifikasi objek dengan posisi objek dirubah dan objek pisau juga diganti dengan pisau yang lain. Tabel 4.2 menunjukkan tingkat akurasi perangkat lunak terhadap perubahan posisi serta perubahan objek pisau.

Tabel 4.2 Tingkat akurasi perangkat lunak

Dari tabel 4.2 terlihat bahwa semua objek pisau dapat dikenali dengan tingkat bahaya tinggi walaupun posisi pisau dipindah serta model pisau yang diganti.

\begin{tabular}{|c|c|c|c|c|c|c|}
\hline \multirow{2}{*}{ No. } & Model & \multirow{2}{*}{$\begin{array}{c}\text { Posisi } \\
\text { Pisau }\end{array}$} & Jumlah Objek & \multicolumn{3}{|c|}{ Tingakat Bahaya } \\
\cline { 5 - 7 } & Teridentifikasi & Rendah & Sedang & Tinggi \\
\hline 1 & 1 & 1 & 2 & 0 & 0 & 2 \\
\hline 2 & 1 & 2 & 1 & 0 & 0 & 1 \\
\hline 3 & 1 & 3 & 1 & 0 & 0 & 1 \\
\hline 4 & 1 & 4 & 1 & 0 & 0 & 1 \\
\hline 5 & 1 & 5 & 2 & 0 & 0 & 2 \\
\hline 6 & 2 & 1 & 1 & 0 & 0 & 1 \\
\hline 7 & 2 & 2 & 1 & 0 & 0 & 1 \\
\hline 8 & 2 & 3 & 1 & 0 & 0 & 1 \\
\hline 9 & 2 & 4 & 1 & 0 & 0 & 1 \\
\hline 10 & 2 & 5 & 1 & 0 & 0 & 1 \\
\hline 11 & 3 & 1 & 1 & 0 & 0 & 1 \\
\hline 12 & 3 & 2 & 1 & 0 & 0 & 1 \\
\hline 13 & 3 & 3 & 1 & 0 & 0 & 1 \\
\hline 14 & 3 & 4 & 1 & 0 & 0 & 1 \\
\hline 15 & 3 & 5 & 1 & 0 & 0 & 1 \\
\hline 16 & 4 & 1 & 1 & 0 & 0 & 1 \\
\hline 17 & 4 & 2 & 1 & 0 & 0 & 1 \\
\hline 18 & 4 & 3 & 1 & 0 & 0 & 1 \\
\hline 19 & 4 & 4 & 1 & 0 & 0 & 1 \\
\hline 20 & 4 & 5 & 1 & 0 & 0 & 1 \\
\hline
\end{tabular}

ideal piksel minimal yang digunakan pada proses filtering adalah 110 piksel. Dimana jumlah objek noise yang terdeksi berkurang namun objek pisau itu sendiri masih terlihat.

\subsection{Identifikasi Objek Pisau Yang Digabungkan Objek Lain}

Pada pengujian kali ini akan dicari seberapa efektif perangkat lunak masih dapat mendeteksi objek pisau yang digabung dengan objek lain namun yang tidak terbuat dari logam. Tabel 4.3 menunjukkan hasil dari perangkat lunak terhadap objek pisau yang digabung dengan objek lain bukan logam.

Tabel 4.3 Hasil Pengujian Perangkat Lunak Pada Objek Pisau Yang Dicampur Dengan Objek Lain 


\begin{tabular}{|c|c|}
\hline Sampel & Hasil \\
\hline 1 & Teridentifikasi \\
\hline 2 & Teridentifikasi \\
\hline 3 & Teridentifikasi \\
\hline 4 & Teridentifikasi \\
\hline 5 & Teridentifikasi \\
\hline 6 & Teridentifikasi \\
\hline 7 & Teridentifikasi \\
\hline 8 & Teridentifikasi \\
\hline 9 & Teridentifikasi \\
\hline 10 & Teridentifikasi \\
\hline
\end{tabular}

Pada tabel 4.3 terlihat, dari 10 kali proses identifikasi objek pisau yang digabung dengan objek lain, 10 kali juga objek pisau teridentifikasi. Sehingga dapat dikatakan bahwa perangkat lunak sangat efektif untuk mengidentifikasi pisau walaupun objek pisau dicampur dengan objek lain yang tidak terbuat dari logam.

\subsection{Identifikasi Objek Pisau Bukan Logam}

Pada percobaan ini dilakukan untuk mengetahui apakah perangkat lunak mampu mengidentifikasi objek pisau yang terbuat dari bahan bukan logam, atau benda mirip pisau seperti pedang-pedangan yang terbuat dari plastik. Tabel 4.4 menunjukkan hasil identifikasi perangkat lunak terhadap objek pisau bukan logam.

4.4 Identifikasi Pada Objek Pisau B
\begin{tabular}{|c|c|}
\hline Sampel & Hasil \\
\hline 1 & Tidak Teridentifikasi \\
\hline 2 & Tidak Teridentifikasi \\
\hline 3 & Tidak Teridentifikasi \\
\hline 4 & Tidak Teridentifikasi \\
\hline 5 & Tidak Teridentifikasi \\
\hline 6 & Tidak Teridentifikasi \\
\hline 7 & Tidak Teridentifikasi \\
\hline 8 & Tidak Teridentifikasi \\
\hline 9 & Tidak Teridentifikasi \\
\hline 10 & Tidak Teridentifikasi \\
\hline
\end{tabular}

Dari tabel 4.4 terlihat bahwa perangkat lunak tidak mampu mengidentifikasi pisau yang terbuat bukan dari bahan logam. Hal ini disebabkan karena pada proses segmentasi menggunakan acuan warna biru dari citra yang menunjukkan bahwa objek tersebut terbuat dari bahan logam.

\section{KESIMPULAN DAN SARAN}

Berdasarkan hasil uji coba dan analisa pada perangkat lunak yang menggunakan proses segmentasi berbasis citra, operasi morfologi pada proses filtering dan tingkat kebulatan untuk mendeteksi objek pisau dari citra mesin x-ray bandara, dapat diambil beberapa kesimpulan. Serta ditambahkan saran dalam pengembangan penelitian berikutnya.

\subsection{Kesimpulan}

1. Nilai ideal piksel minimal yang digunakan pada proses filtering adalah 110 piksel. Dimana jumlah objek noise yang terdeksi dapat berkurang namun objek pisau itu sendiri masih terlihat.

2. Dengan perangakat lunak yang dikembangkan, objek pisau dari bahan logam dapat dikenali dengan tingkat bahaya tinggi walaupun posisi pisau dipindah serta model pisau diganti.
3. Perangkat lunak dengan algoritma yang ditawarkan dinilai sangat efektif untuk mengidentifikasi pisau walaupun objek pisau dicampur dengan objek lain yang tidak terbuat dari logam.

4. Perangkat lunak dengan algoritma yang ditawarkan, tidak mampu mengidentifikasi pisau yang terbuat bukan dari bahan logam. Hal ini disebabkan karena pada proses segmentasi menggunakan acuan warna biru dari citra yang menunjukkan bahwa objek tersebut terbuat dari bahan logam.

\subsection{Saran}

1. Untuk penelitian berikutnya selain parameter warna pada proses segmentasi, bisa ditambahkan juga parameter bentuk. Sehingga baeang berbahaya lain dapat diidentifikasi dalam satu proses saja. 
2. Pada proses identifikasi dapat ditambahkan algoritma cerdas untuk mengidentifikasi objek berbahaya dari citra X-ray bandara.

Perangkat lunak yang dikembangkan untuk identifikasi barang berbahaya dari citra x-ray bandara dapat menjadi kesatuan dengan sistem di mesin $\mathrm{x}$-ray itu sendiri.

\section{DAFTAR PUSTAKA}

[1] Peraturan Direktur Jendral Perhubungan Udara. (2010). Tata Cara Pemeriksaan Keamanan, Penumpang, Personel Pesawat udara dan Barang Bawaan yang Diangkut dengan Pesawat udara dan Orang Perseorangan. Nomor: SKEP/2765/XII/2010

[2] Hardmeier D. (2005) The X-Ray Object Recognition Test (x-ray ort) - A Reliable and Valid Instrument for Measuring Visual Abilities Needed in X-Ray Screening. Department of Psychology, University of Zurich, Switzerland.

[3] Schwaninger A. (2007) A Statistical Approach for Image Difficulty Estimation in X-Ray
Screening Using Image Measurements. Department of Psychology, University of Zurich, Switzerland Max Planck Institute for Biological Cybernetics, T"ubingen, Germany

[4] Khaparde A. (2010) Face Detection Using Color Based Segmentation and Morphological Processing - A Case Study. Bharath Institute of Science and Technology Aurora's Technological and Research Institute, Hyderabad.

[5] H.J.C Liujten (2005). Basic of Color based Computer Vision Implement in Matlab DCT 2005.87.

[6] Murinto Eko Aribowo, Wahyu N. (2001). Deteksi Jenis Warna Kulit Wajah untuk Klasfikasi Ras Manusia menggunakan Transformasi Warna. Universitas Ahmad Dahlan Jogjakarta

[7] Linda G Shapiro, George C Stockman (2001). Computer Vision. pp. 279-325, New Jersey, Prentice Hall.

[8] Alan Bovic.(2009). The Essential Guide to Image Processing.

[9] Indah Susilawati. (2012) Teknik Pengolahan Citra. Mathematical Morphology. Universitas Mercu Buana, Yogyakarta 